\title{
Applying the system viability framework for cross-scalar governance of nested social-ecological systems in the Guiana Shield, South America
}

\author{
$\underline{\text { Andrea Berardi }}^{1}, \underline{\text { Jayalaxshmi Mistry }}^{2}$, Céline Tschirhart $^{2}, \underline{\text { Elisa Bignante }}^{3}$, Odacy Davis $^{4}, \underline{\text { Lakeram Haynes }}^{5}, \underline{\text { Ryan Benjamin }}^{5}$, \\ Grace Albert $^{5}, \underline{\text { Rebecca Xavier }}^{5}$, Deirdre Jafferally $^{4}$ and Géraud de Ville ${ }^{1}$
}

\begin{abstract}
Linking and analyzing governance of natural resources at different scales requires the development of a conceptual framework for analyzing social-ecological systems that can be easily applied by a range of stakeholders whose interests lie at different scales, but where the results of the analysis can be compared in a straightforward way. We outline the system viability framework, which allows participants to characterize a range of strategies in response to environment challenges for maintaining the long-term survival of their particular system of interest. Working in the Guiana Shield, South America, and with a range of local, regional, and international stakeholders, our aim was to use system viability to (1) investigate synergies and conflicts between distinct scales of governance, (2) identify scale-related challenges, and (3) test the framework as a conceptual tool for supporting cross-scalar analysis for environmental governance.
\end{abstract}

At the international and national levels, a number of civil society organizations explored system viability indicators that would measure the successful implementation of governance mechanisms relevant to sustainable development and natural resource management. At the local level, we used participatory video and photography within two indigenous territories to enable local participants to identify indicators of viability within community governance systems. A grounded theory approach was then used to identify common themes across the different scales of analysis.

Five key themes emerged: land rights, leadership, partnerships, lifestyle, and identity. We found that although most categories of interest were theoretically aligned across scales, all perceived systems of interest were struggling to face up to various cross-scalar challenges undermining different system viability responses. In conclusion, we highlight how the system viability framework can be used with a disparate variety of stakeholders as a practical, participative and "big-picture" approach for facilitating the integrated governance of nested local and regional social-ecological systems.

Key Words: Brazil; environmental governance; Guiana Shield; Guyana; natural resource management; participatory video; sustainability indicators; system viability

\section{INTRODUCTION}

The world is experiencing a shift in environmental governance away from monocentric state control toward multicentric levels of decision making, encompassing international, national, and local agreements and organizations, and including the full spectrum of first, second, and third sector organizations (Termeer at al. 2010). Significant emphasis has been placed, both by practitioners and governance theorists, on institutional arrangements, such as the promotion of cross-scalar institutions tasked with integrating and mediating between the interests of stakeholders at different scales (Ison et al. 2015). Processes proposed for facilitating cross-scalar integration range from the highly structured and top-down, where prescriptive frameworks require stakeholders to provide information within preestablished categories established by experts, to the highly participatory and bottom-up, where stakeholders are facilitated through a participatory process of model development. Reed et al. (2006), for example, present a range of bottom-up and topdown approaches used to identify sustainability indicators. Both extremes of bottom-up and top-down approaches have their problems: pre-established expert-led structure may stifle the expression of a variety of diverse perspectives, while participatory approaches may require significant time and effort for stakeholders to arrive at a shared understanding, and still not deliver the "scientific" results required by decision-making institutions. We present the system viability approach, an adaptation of orientor theory (Bossel 2001), as a middle ground between bottom-up and top-down approaches in an attempt to find a balance between providing structure and allowing stakeholders to represent their particular interests.

We apply the system viability approach to a cross-scalar analysis of environmental governance in the Guiana Shield region of South America. In our case study, we focus on ongoing attempts to enhance the survival prospects of this region; a vast area of 2.5 million square kilometres encompassing the watersheds of the Amazon, Orinoco, and Essequibo rivers, and a series of smaller rivers draining directly into the Caribbean and the Atlantic Ocean. The Guiana Shield extends into six different countries (Brazil, Colombia, Venezuela, Guyana, Suriname, and French Guiana) and is the world's largest contiguous block of tropical rain forest, characterized by the highest percent of forest cover and lowest rate of deforestation on the planet, and containing $10-15 \%$ of the world's fresh water reserves. The region is one of the world's most significant reservoirs of biodiversity, and is home to many hundreds of distinct indigenous cultures.

${ }^{1}$ The Open University, ${ }^{2}$ Royal Holloway University of London, ${ }^{3}$ Department of Cultures, Politics and Society, University of Torino, ${ }^{4}$ Iwokrama International Centre, ${ }^{5}$ North Rupununi District Development Board 
The aim of our analysis was to develop and test the system viability approach. Stakeholders within the Guiana Shield region, operating at a range of scales, used the system viability approach to surface their perspectives on what they believed were significant indicators for the protection of the Guiana Shield's ecological and cultural diversity. This enabled us to integrate their varied perspectives by comparing their selected System Viability indicators, so as to identify cross-scalar environmental governance challenges, which we then used to inform specific policy-making initiatives in the region. In this paper we present the theoretical underpinnings of the system viability approach for cross-scalar environmental governance, the process of stakeholder engagement, an overview of the resulting indicators, our cross-scalar analysis, and a critical appraisal of the system viability approach and stakeholder engagement process.

\section{ENVIRONMENTAL GOVERNANCE ACROSS SCALES}

There is growing consensus that governing environmental challenges is about engaging with a variety of stakeholder perspectives that operate at a range of scales (Cash et al. 2006). Many environmental issues, such as climate change, loss of biodiversity, and water management, are multifaceted where changes and/or interventions proposed by one stakeholder at one scale can significantly impact on other scales and other stakeholders. This implies that effective management and governance of environmental challenges requires an understanding of the multiple, networked, and dynamic interrelationships between stakeholders operating at different scales (Pierre and Peters 2000). However, to date, many policies and actions have supported management solutions/policy interventions that have mostly come from higher scale institutions, e.g., national governments and nongovernmental organizations, which are not always compatible with the realities and perspectives of smaller scale stakeholders, e.g., isolated rural communities and their local environments (Warburton 2009).

Linking and analyzing environmental governance at different scales requires the development of integrative conceptual models with which a range of stakeholders, at varying levels of capacity, can engage. However, few conceptual models currently used in environmental policy and practice provide a fully integrative approach that looks at the potential synergies and conflicts across social, economic, technological, and ecological domains at different scales of organization (see Wunder et al. 2008, Carpenter et al. 2009). Crucially, these models have rarely been articulated by the most marginalized groups of society (Peskett et al. 2008). This is vital not only for making the connections among technological, economic, ecological, and social structures and processes and aspects of monetary and nonmonetary measures of human and ecological well-being, but also for quantifying trade-offs and developing appropriate management actions and policy interventions in increasingly dynamic and unpredictable scenarios (Cowling et al. 2008). The integrative model building process therefore needs to involve all stakeholders, but particularly the most marginalized sectors of society (Blom et al. 2010). Marginalized communities, such as indigenous peoples, are usually the ones that have the most direct contact with the environment, yet have the most to lose from environmental degradation (e.g., Martin et al. 2013) while at the same time are least able to engage with decision-making processes occurring at national and international levels (Taylor 2006, Nakashima et al. 2012). Nevertheless, we need to recognize that there is no one reliable source of knowledge; there is a politics of scale on which actors with different knowledge claims will try to leave their mark on how issues are analyzed and addressed (Buizer et al. 2011).

With this in mind, and a focus on the Guiana Shield region of South America, we describe how stakeholders across a range of scales engaged with a system viability framework to elicit a range of strategies that these stakeholders felt were important for the survival of nested social-ecological systems in the region. Our aims were to (1) explore synergies and conflicts between scales of understanding in environmental governance, (2) illustrate some of the scale-related challenges, and (3) test system viability as a tool for cross-scalar integration of stakeholder perspectives in environmental governance. This final aim was particularly important because a key outcome of the research was to investigate the feasibility of the approach for integration into major decision-making frameworks for determining the socialecological future of the Guiana Shield region.

\section{SYSTEM VIABILITY}

Central to our approach is the concept of system viability, a simplification and adaptation of orientor theory (Bossel 1999). Systems can be defined as components that interact together to achieve a particular purpose. Systems do not operate in a vacuum, but need to respond to the challenges and opportunities available within their environment. Thus, system viability is about the processes and structures a system develops to guarantee its survival in the long term in response to environmental opportunities and challenges. However, we also acknowledge that systems do not exist "out there"- they are mental constructs that we develop to help us engage with the overwhelming complexity of the real world. It is therefore essential to understand how different stakeholder groups identify and perceive their system of interest.

Orientor theory is part of a broad family of frameworks within the "systems thinking" tradition, aimed at supporting the management of complex situations (Bossel 2007). Since the emergence of the theoretical foundations to systems thinking in the 1940s to the 1960s (Ashby 1956, Bertalanfy 1956, Churchman 1968), various frameworks and approaches have been proposed to support decision making within complex interconnected situations, where those involved have contrasting understandings, motivations, and interests, and where conflicts inevitably arise. The tools within the systems tradition include system dynamics and the viable systems model, which have been developed to primarily deal with feedback, interrelationships, and interdependence (Forrester 1961, Beer 1985). Other approaches include soft systems methodology and strategic options development and analysis with cognitive mapping (primarily dealing with appreciating and mediating between multiple perspectives) and critical systems heuristics (primarily dealing with ethics and politics; Checkland 1981, Eden and Ackermann 1988, Ulrich 1987). All of these approaches have been applied to the problem of environmental governance, from Meadows et al. 's (1972) use of system dynamics to model global resource limits, to Bunch (2003) facilitating a range of stakeholders in using soft systems methodology in an effort to rehabilitate the Cooum River and environs in Chennai, India. Although all of these approaches have useful and distinctive roles to play in environmental management and governance, our objective was to identify and test a relatively straightforward systems framework for comparing 
Fig. 1. System viability framework.

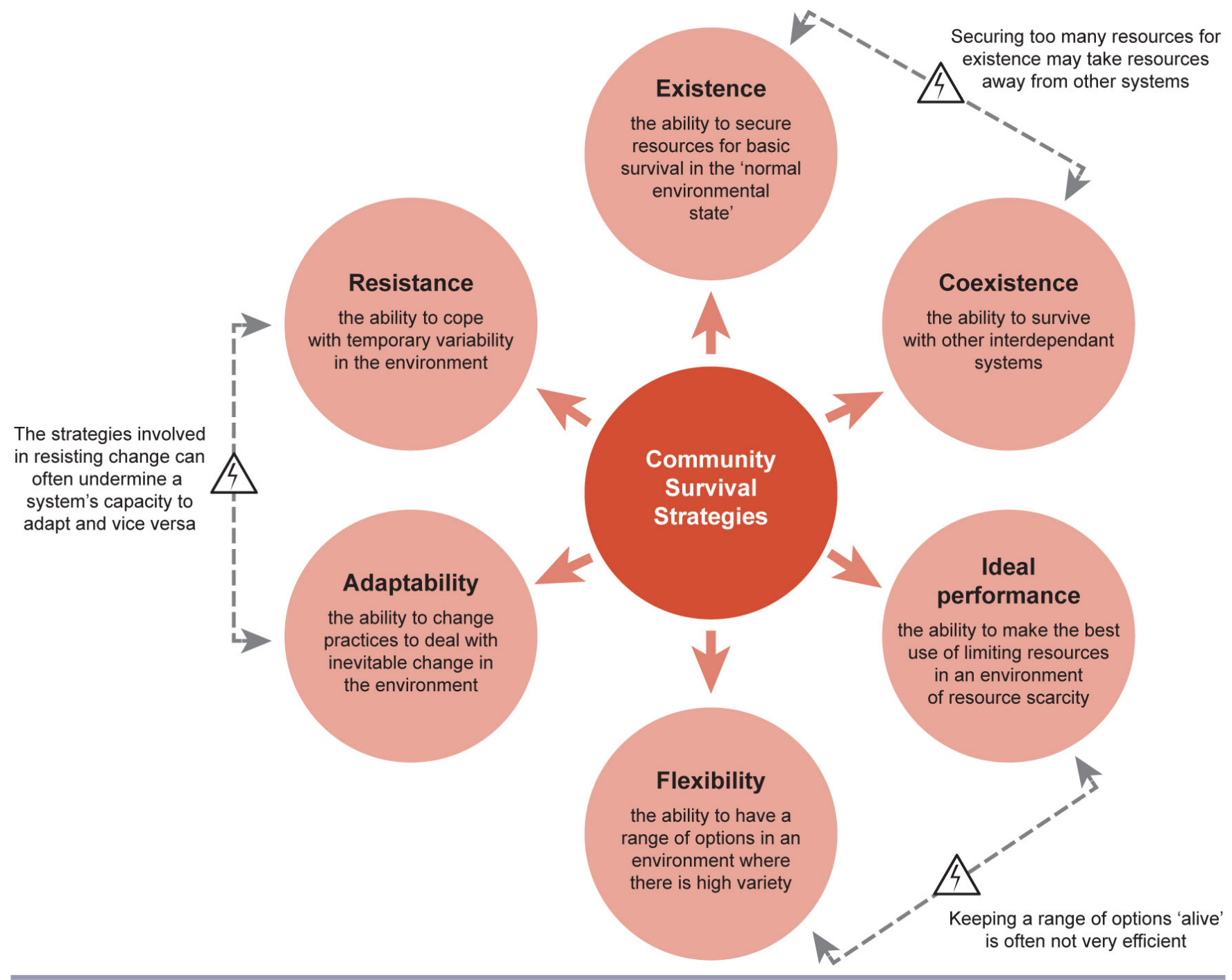

and mediating stakeholder views that operate at different levels of environmental governance. We say "straightforward" because all of the above approaches suffer from requiring high levels of professional expertise to operationalize. For example, we did not want to make use of inaccessible "black box" mathematical modeling, as in system dynamics, or to follow a complex and timeconsuming series of facilitated exercises that involved gathering all stakeholders in one place, as in soft systems methodology. In keeping with the systems tradition, we were still looking for an approach that surfaced distinct stakeholder perspectives in a big picture exploration of the ecological and cultural situation in the Guiana Shield, but which would allow individual stakeholders relative autonomy in the modeling process while producing results that could be readily integrated into a cross-scalar analysis.

For a systemic cross-scalar analysis to take place, we needed to apply a systems framework that allowed a comparison between system properties at different scales. Systems theorists such as Eugene Odum and Hartmut Bossel have directed their efforts toward identifying and describing certain system features that are regularly changed by self-organizing development (Odum 1969, Bossel 1998). These theorists have identified a range of system attributes that can be grouped as collective properties that are expected to be regularly optimized during the development of any system (Bossel 1998). In other words, there are distinct environmental conditions that any system has to develop adaptive responses toward, and Bossel (1992) has characterized six distinct "orientors" that any system has to accommodate to maximize its chances of survival. Bossel (2001) has demonstrated that this structured approach, based on systems theory and empirical evidence, can allow sustainability practitioners to obtain a comprehensive set of indicators that cover all important aspects of system viability and performance, and can therefore guide decision making in environmental governance across different scales of analysis.

When we adapted Bossel's orientor theory in our investigation, we focused on the need to facilitate stakeholders' expression of 
what they believe is necessary for their system of interest to react to challenges from the system's environment to maintain its health and viability. To support stakeholder explorations of their systems of interest, we simplified and adapted orientor theory (Bossel 1992, 1999) to six fundamental responses to distinct environmental conditions (Fig. 1). These "orientors," or survival strategies, have been reinterpreted by Mistry et al. (2010):

- Existence: the ability to secure resources for basic survival in the normal environmental state;

- Coexistence: the ability to coexist with other interdependent systems;

- Ideal Performance: the ability to make the best use of limiting resources in an environment of resource scarcity;

- Flexibility: the ability to have a range of options in an environment where there is high variety;

- Resistance: the ability to cope with temporary variability in the environment;

- Adaptability: the ability to change practices to deal with inevitable change in the environment.

In many cases, there are tensions between system strategies. Any strategy in response to an environmental challenge that threatens a perceived system's survival implies that a system needs to dedicate resources to face and/or adapt to the challenge. Most systems are perceived as not having an unlimited resource supply, and therefore trade-offs need to be made between investing in different system responses:

- A system's need to secure resources for basic survival can often conflict with its ability to share these resources with interdependent systems;

- A system's ability to make best use of limiting resources by investing in optimizing certain functions can conflict with its ability to maintain a wide range of functions so as to give maximum flexibility in an environment with high variety;

- Finally, a system's ability to resist change by investing in existing functions and structures can conflict with a system's ability to adapt to novelty within its environment by investing in new functions and structures.

An ideal system would be able to accurately measure current environmental challenges and predict their future state, allocating the right balance of resources to the six different responses. However, it is often the case that a system either has no predictive ability or the system's future environment is unpredictable. In these situations, the best pragmatic strategy is to appropriately distribute effort to all six responses.

Orientor theory has been used to analyze the viability of family units, businesses, regional plans, agricultural systems, ecosystems, and nations (Müller and Leupelt 1998, Bossel 1999, 2001, 2007, Mistry et al. 2010). However, in our adaptation of this approach, simplified to a more accessible system viability framework, we propose that systems are social constructs determined by people's values and experiences. Thus, the strength of how we apply the system viability approach is that it enables distinct stakeholder groups to surface their values and agency by allowing them to express what they perceive to be the strategies required for their system of interest to survive in the long term. Distinct stakeholder groups are supported in characterizing their systems of interest and these are in turn scrutinized to examine how these perceived systems across scales interact to create emergent counterproductive or synergistic situations that undermine or sustain the viability of these perceived systems. As the implication of the survival strategies of distinct systems of interest are manifested, the possibility for negotiating a possible way forward to potentially conflicting interests presents itself through a focus on synergistic strategies.

One would be justified in thinking that the system viability approach is a highly abstract conceptual framework. Indeed, this is its key advantage. Without providing predefined categories for characterizing a stakeholder's system of interest, each stakeholder is allowed to freely explore and propose a range of specific strategies for survival. The key is that these specific strategies are able to represent the full range of system responses. Understandably, abstract explanations can be very difficult to engage with, but readily accessible examples can be derived from everyday life:

- Do I take all the resources myself (food, money, consumer goods) or do I share these with others (existence versus coexistence)?

- Do I become really good at one thing or do I learn to do all sorts of things, but not so well (ideal performance versus flexibility)?

- In the face of difficulties, do I insist on doing what I have always done or do I change what I'm doing (resistance versus adaptability)?

To note that although the above example is presented through a range of dualisms there are also system survival strategies that are synergistic. For example, learning to speak a foreign language, which could be considered an adaptive response to an increasingly multicultural environment, may also enhance your ability to teach your native language to others, which could be considered a resistance response by strengthening one's own culture. Fundamentally, the system viability approach moves away from the typically unidirectional normative judgement that suggests that one strategy for survival is clearly wrong and another is clearly right, e.g., from undeveloped to developed as implied in the term "sustainable development." Instead, it allows stakeholders to appreciate that every system has its tensions, and often the challenge is to find the appropriate balance between strategies, or preferably, survival strategies that act synergistically.

The system viability approach acknowledges that systems can be perceived as having to cope with a wide variety of environmental conditions. System viability is not only about coping with change. The term "resilience," although attractive to many, continues to present difficulties in precisely articulating how its characteristics can be measured in practice (Carpenter et al. 2001, Gallopín 2006, Berardi et al. 2013a). Although some aspects within a system's environment can be perceived as undergoing permanent change (requiring a focus on an adaptive response), some other aspects may very well be perceived to be stable (requiring an existence response), or undergoing temporary change (requiring a resistance response), becoming scarcer (requiring an ideal performance response), diversifying (requiring a flexibility 
response), or introducing competitive and/or cooperative opportunities (requiring a coexistence response).

The six system viability strategies thus provide a wide range of categories to allow users to identify indicators for evaluating the long-term survival of systems, whether social, ecological, or a combination of both. They also allow users to identify trade-offs and synergies between system viability strategies, something that is significantly more difficult to operationalize when adopting a resilience model. In a wide-ranging review of sustainability indices, Reed et al. (2006) single out orientor theory, from which our simplified system viability approach has been derived, as one of the most holistic and comprehensive to date.

\section{CONTEXT AND METHODOLOGY}

This research focuses on the Guiana Shield region of South America, which extends from Colombia in the west to Brazil in the east (Fig. 2), covering an area of 2.5 million square kilometres,

Fig. 2. Map of the Guiana Shield, South America (kindly drawn by Sarvision 2010).

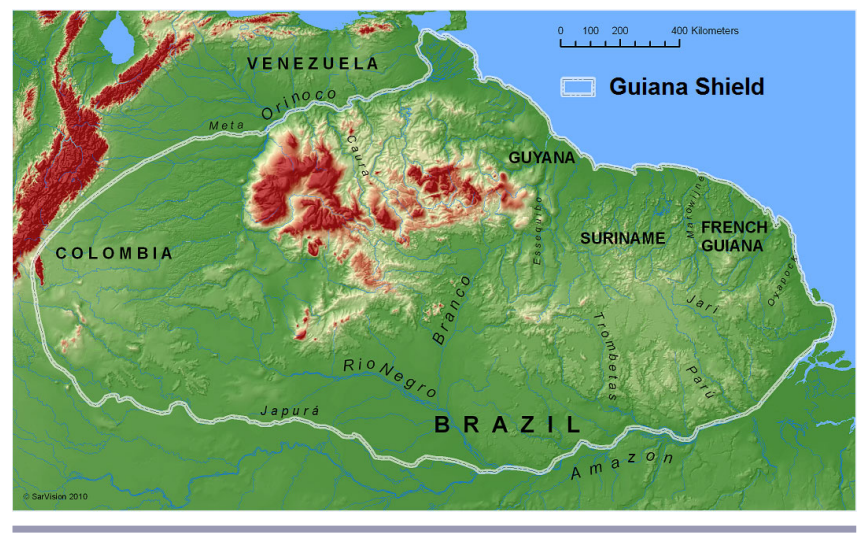

and including parts of the watersheds of the Orinoco and Amazon rivers (Hammond 2005). With its valuable fresh water reserves, low deforestation rates, and rich biodiversity, it has been the focus of considerable conservation efforts, payment for ecosystem services (PES) schemes, and climate change mitigation and adaptation financing (Mistry et al. 2009, Berardi et al. 2013b). Brazil, for example, has formally protected vast areas of the Amazon region, either as biodiversity conservation areas or indigenous territories. However, Brazil is also the world's fourth largest emitter of greenhouse gases, with a significant contribution from deforestation in the Amazon basin (Matthews et al. 2014). After years of decreasing deforestation rates, recent data show that deforestation is sharply on the increase (BBC 2013). Brazil has also made significant discoveries of offshore fossil fuel deposits that could make it one of the largest oil producers in the world. This ambiguous position on the world stage, on one side as a nation that strives to conserve and protect natural ecosystems and indigenous cultures, and on the other, as an increasingly significant global emitter of greenhouse gases, means that its international and national policies are often working against each other (Bond et al. 2009).

At the other extreme within the Guiana Shield region, we have Guyana, which has only recently passed legislation to protect natural landscapes and traditional indigenous territories, while on the other hand, is actively seeking to be seen as one of the leading countries that integrate sustainable ecological management as part of its development strategy (Chene 2010). Two particular policies championed by the Government of Guyana are the adoption of the Low Carbon Development Strategy and the United Nations Framework Convention on Climate Change's (UNFCCC) Reduction of Emissions through Deforestation and Degradation (REDD+) framework, both reorienting the economy from a resource extraction development paradigm to a supplier of environmental services (Chung Tiam Fook 2013, Mistry 2014).

In both Brazil and Guyana, we know little about the extent to which international and regional policies, implemented at the national level, are compatible with current lived realities of indigenous communities inhabiting the very places where the policies may be implemented. One particular area of concern, for example, is that Guyana's Low Carbon Development Strategy also includes investment into major infrastructural projects for transportation, large dams like the controversial Amalia Falls Dam, high-end industrial agriculture, and "sustainably" managed logging and mining activities that will undoubtedly have a major impact on traditional indigenous livelihoods and associated natural ecosystems (Griffiths and Anselmo 2010). This is particularly significant considering that indigenous communities occupy significant tracts of territory and are therefore most likely to play a key role as stewards for monitoring forests in various schemes for PES and climate change mitigation (Danielsen et al. 2013).

Within this context, Project COBRA, funded by the European Commission, aimed to integrate community owned solutions to social-ecological challenges within policies, through accessible information and communication technologies in the Guiana Shield (see http://projectcobra.org/). The project involved partners across Europe and South America including indigenous community groups, civil society organizations (CSOs), and research institutions. The first phase of the project involved using the system viability framework to support stakeholders in identifying systems of interest, and developing indicators of system viability according to the six response strategies. In other words, knowledge at the scale at which actors frame and present their knowledge and worldviews was collected (Ahlborg and Nightingale 2012). Part of the research included the perceived status of social-ecological systems at regional and local level.

At the local level, we worked within four case study indigenous territories: three in the North Rupununi, Guyana, and one in Tumucumaque, Brazil. As well as drawings, we used participatory photography (PP; Bignante 2010) and participatory video (PV; White 2003, Lunch and Lunch 2006, Mistry and Berardi 2012) as research tools to stimulate people's interest in the research and to enable participants to identify systems of interest on their own terms using a communication mode that is familiar to them (visual compared to textual). Local indigenous researchers facilitated the process of discussing, capturing, and editing (into films and photostories) community viability indicators according to the six system viability strategies, indicator thresholds, and data in collaboration with wider community members. The aim of facilitating the establishment of indicators and thresholds was to 
allow community participants to assess the effectiveness of specific strategies of community viability by comparing these to actual observations within the communities. For a comprehensive outline and critique of the use of participatory video and photostories within our research, see Mistry and Berardi (2012), Mistry et al. (2014a, b), and Mistry et al. (2015). Once the video and photographic materials were submitted to the project, they were analyzed by project researchers through a process of coding individual segments/photos based on visual and audio content, using the NVivo qualitative software. The results were then presented to the indigenous researchers through in-depth discussions, and the representations of indicators and their relationships were adapted and refined where necessary. Final indicators and the associated data exploring the perceived viability of each community were then presented back to the wider communities for final agreement and comments. The whole process of indicator development took place over 18 months.

At the international and regional scales of analysis, various civil society organizations (CSO) and research institutes undertook a comprehensive desk-based review of established policy frameworks relevant to sustainable development and natural resource management in the Guiana Shield region, i.e., these were identified as key systems of interest. This then resulted in the development of viability indicators for two distinct systems of interest at two distinct scales: the international policy environment; and the detailed national/sub regional contexts within two Guiana Shield countries (Brazil and Guyana). For the purposes of this paper, we will focus on comparing the results from the community and national/subregional contexts.

For the national/subregional levels, a range of published and unpublished academic and grey literature was used to compile the system viability indicators for sustaining the viability of the Guyanese North Rupununi and Brazilian Tumucumaque region social-ecological systems. These investigations were carried out by a Guyanese conservation CSO and a consultant working for a Brazilian CSO respectively, reflecting the approach suggested by Keohane et al. (1993:7) where there is a "focus on observable political effects of institutions rather than directly on environmental impact." The majority of indicators identified by these CSOs focused on institutional and human capacity within Brazil and Guyana. This was considered an appropriate strategy because national strategies rarely have a direct connection with the environmental and social impact on the ground, but rather, depend on sovereign states initiating regional and local initiatives. These in turn create and reinforce institutions that mobilize human capacity to result in a positive social and environmental impact on the ground.

To further support critical scrutiny of indicator selection, we applied a qualitative scoring system to each indicator, following other indicator studies including Mistry et al. (2010), Béné et al. (2011), and Davis et al. (2013). The status of each indicator was evaluated and given a score of 1-3: 1-inadequate, 2-acceptable, and 3-good. This was done using both primary data, through records and information from Project COBRA activities (e.g., at the community level, meetings were organized with community members to establish indicator thresholds and evaluate the indicator status), and secondary data from government, NGO, and international agency reports. This was collated by the paper authors and further clarified with literature reviews and communication with Project COBRA participants. Once indicators were scored, an average value was calculated for each system property at each scale, and these final average values are illustrated in Figure 3. Full details of the methods and analysis at each level are given in Berardi et al. $(2012,2013 a, b)$ and participatory videos and photostories can be accessed at the Project COBRA web site.

Fig. 3. Star diagram showing average values for each system property at each scale of analysis.

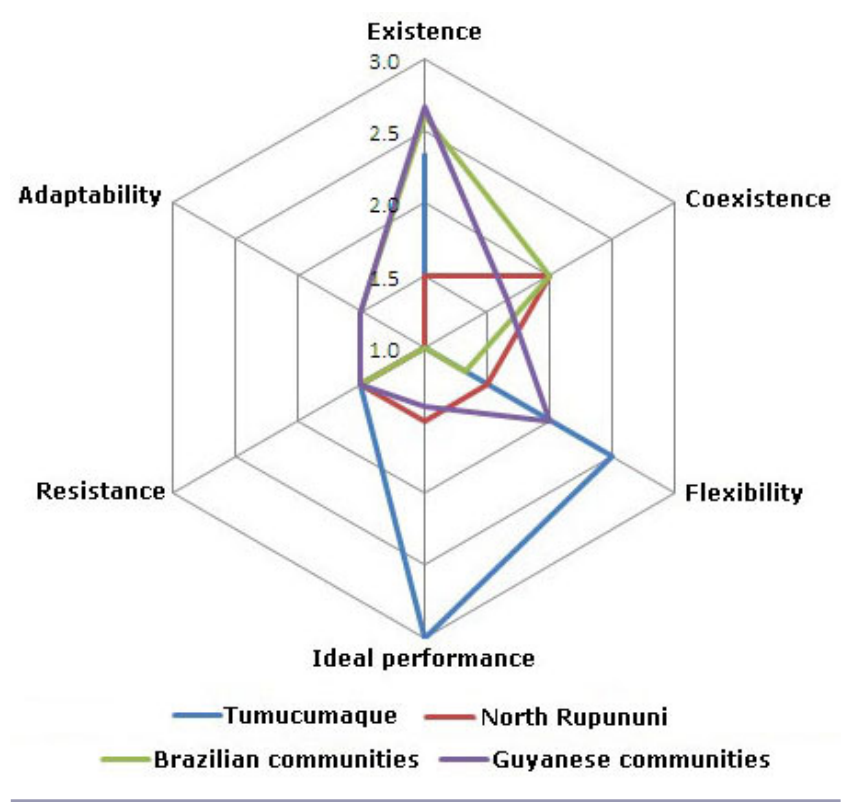

\section{INDICATORS OF VIABILITY OF NESTED GUIANA SHIELD SYSTEMS}

All the indicators identified by the participants are considered to say something directly or indirectly about how indigenous communities and the ecosystems of the Guiana Shield are affected by, and react to, the various challenges in the region, and how national and international policies are having an impact. We present indicators identified by the communities in the North Rupununi and Tumucumaque region, and explore the indicators identified by national CSOs for the wider region surrounding these communities.

\section{Indicators of system viability at community level}

The videos produced by communities of the North Rupununi strongly emphasized that their existence strategy for coping with routine environmental challenges relied on access to land, which was closely linked to having a land title. The videos showed that land encloses all the elements they require to meet their basic needs during stable environmental conditions. Visual representations of existence indicators typically included the following:

- Forests, used for hunting, gathering fruits, and medicinal plants, extracting wood for domestic use (firewood, construction wood for homes and canoes);

- Farmland to grow their staples. More specifically, cultivating cassava (Manihot esculenta) is of high importance because it is a major component of their diets. 
Many cassava by-products are essential in everyday life, like cassava bread, cassava farine, cassava drinks.

- Rivers were shown as essential for fishing, domestic use, and transportation.

To be able to resist temporary change, two main indicator themes emerged within the videos: maintaining and passing on traditional practices and culture, and protection of the natural environment. To keep their identity, communities of the North Rupununi captured imagery of practices for transmitting traditional skills and culture to youth. This involved simple daily tasks like processing cassava, but also building traditional weapons like bows and arrows, knowing how to weave cotton, speaking the native indigenous language, and knowing dances, songs, and stories. To achieve the protection of the natural environment, communities identified the presence of conservation areas, community rules for sustainable use of resources, and establishing and applying strong protective laws at national and local scales. During community discussions for selecting resistance indicators, many people felt that maintaining traditional practices also ensured that the environment is used in a sustainable way during times when environmental conditions temporarily vary from the norm.

Videos focusing on flexibility strategies for coping with a diverse environment showed that flexibility was achieved through adopting a variety of farming techniques, but also by maximizing options in terms of access to healthcare, food, and income. To make sure communities were flexible in terms of food security, community contributors to the videos mentioned adopting a variety of farming techniques: a mixture of low-lying grounds to support crops during periods of drought and farms on higher grounds for cultivation where soils were more productive during excessive flooding; planting new varieties of cassava that are more resistant and productive; and cultivating a wide variety of crops to avoid being dependant on one staple. Moreover, having a paid job was seen as enabling individuals within the communities to buy food from shops, which greatly expanded their flexibility in terms of food security, but also in many other domains. In terms of coping with the diverse challenges of a great variety of diseases and other health issues, the three communities highlighted maintaining the choice of access to three types of health services: local traditional practitioners, community health posts and health workers, medical centers and hospitals in towns and cities.

Adaptability indicators for confronting new and emerging challenges were associated with everything that was not deemed to be traditional, such as new mediums of transport, e.g., bicycles, motorcycles, cars, lorries, new mediums of communication (e.g. radio, television, computers, internet), new material for homes (e. g. tin roofs), new food types, e.g., canned meat, new music, e.g., Brazilian popular music, new water collection and distribution facilities, e.g., plastic containers and piping, and new forms of energy generation, e.g., solar panels. It is interesting to note how indigenous communities perceived their responses to adapting to a changing world by incorporating nonindigenous goods and tools. By knowing about and using these tools, the North Rupununi communities mention within the videos that they can keep up to speed and interact with the rapid changes brought about by the increasing connection to the outside world, perceived to be the major source of permanent change within communities.
Because coexistence is about coping with other systems in the community's environment, the videos exploring coexistence focused on institutions and groups of people familiar to the communities, such as the North Rupununi District Development Board (NRDDB), the Iwokrama International Centre for Rainforest Conservation and Development (IIC), the Guyanese Government, and neighboring communities. Indicators of the level of interaction with these different partners were identified as the number of meetings, but also the amount of funding emerging out of these partnerships, the number of development projects, the establishment of management plans, law enforcement capacity to regulate resource use by noncommunity members, and the provision of services such as schools and health posts.

The efficient use of titled land was the main theme identified within the ideal performance strategy videos. Although land was not necessarily felt as a scarce resource per se, the fact that it was perceived to be geographically limited through restricted land titling, meant that, for the communities, they were increasingly forced to make the most of their limited resources. Thus, the presence of community management plans and projects for the sustainable use of resources were chosen as important indicators for measuring efficient use of surrounding land. However, to be efficient, some communities also acknowledged the importance of having a good leader, having training, having a dynamic and cohesive community with a balanced age structure. Keeping youth in the communities, a healthy and able workforce, was underlined as an important indicator of ideal performance in the North Rupununi communities.

The costs and logistics of engagement with the highly isolated indigenous Tumucumaque communities meant that exploration of system viability indicators was not as in-depth as those emerging from the North Rupununi communities. However, it is worth including here because it is important to compare results between geographically, historically, and culturally distinct communities. In Tumucumaque, indicators exploring existence strategies of the Tiriyó and Kaxuyana communities focused on a blend of physical and social elements. Forests and clean rivers played an essential role to meet basic needs during normal environmental conditions. The videos produced within these communities showed that these provide fish, fruits, deer, and turtle. Clean rivers were also shown to be important for domestic use (drinking water or to prepare food), as well as recreation, i.e., to maintain a community's social life. However, in terms of food, a theme that repeatedly came up when exploring the existence strategy was the important staple of cassava. Again, the videos not only showed key cassava by-products, like cassava farine or cassava bread, but also a drink called sakura, which is consumed daily and plays a major role in the community's social life, being at the center of all celebrations. Finally, the existence strategy of the community was felt to rely greatly on good leadership, and fights were presented within the videos as an indicator of the quality of the leadership: "with bad leadership quarrels arise." It is useful to note here that the North Rupununi communities had proposed the quality of leadership under the ideal performance strategy instead, rather than the more fundamental existence strategy. This may suggest different levels of conflict among communities, in that Tumucumaque communities may feel that good leadership was needed to deal with internal conflicts that 
were seen as a challenge characteristic of the normal, day-to-day social environment, whereas the North Rupununi communities required good leadership mostly to deal with the efficient use of resources.

Videos exploring resistance indicators within the Tumucumaque communities showed that Tiriyó and Kaxuyana resist change by keeping united and through solidary. Thus, they resist by bringing people together for celebrations, by communicating in their own language, by carrying out daily tasks in a group, such as fishing and hunting, working in the fields, or building homes. Again, leadership is shown as an important indicator for dealing with environmental challenges that emerge occasionally.

Flexibility was highlighted in three main areas: food, health, and transport. The introduction of non-native food in the indigenous territory, and its commercialization in small shops or by certain people, mainly identified as "whites," gave more choice when food could not be extracted from the surrounding natural environment. Access to a diversity of health services was suggested by the communities as expanding the possibilities of getting medical treatment. Facing a health problem, the videos show how communities in Tumucumaque have the choice between traditional medicine (plants and traditional practitioners), community health posts, and being sent to the Casa de Saúde Indigena (Indigenous Health Home) in the state capital, Macapá. Finally, the introduction of new modes of transport within Tumucumaque, i.e., bicycles, motorcycles, cars, tractors, boat engines, also expands mobility for cultivating, hunting, or fishing because it enables people to go further and quicker if necessary.

Just as in the North Rupununi, the communities in Tumucumaque perceived permanent change within their environment as all the new non-native equipment and institutions that the local community was increasingly being exposed to. Tumucumaque indicators of adaptability were the ability to use a high frequency radio, computers, or TV; new mediums of transport; all kinds of objects like cooking pots, brush cutters, motorized cassavagrating machines, generators, and firearms. The ability to source gasoline and diesel are shown as one key indicator of adaptability within an isolated region, without which most of the new technologies would not function. Finally, to adapt to a changing world, to communicate with it, to understand it, church, government schools, and health posts were seen as playing important roles as mediators.

Tumucumaque communities used very similar indicators for characterizing their ideal performance strategies as the ones proposed for adaptability. All the new non-native equipment the local community has adapted to, was also seen as enabling them to carry out traditional tasks much quicker or further away. The non-native equipment enabled the community to be more efficient at many fundamental livelihood tasks that required the processing of and/or access to scarce resources. So, for example, access to a hunting gun would allow community members to continue securing wild game at a time when wild game was seen to have become increasingly scarce.

Interaction between different Tumucumaque communities was identified as a crucial indicator of coexistence with other system. Relations with stakeholders like the Franciscan fathers within Tumucumaque territory, or the nearby Brazilian military base was also mentioned in the videos. Imagery of a plane on a runway is seen as embodying the relations with stakeholders outside of the Tumucumaque territory.

\section{Indicators of system viability at the regional level}

The existence of the North Rupununi social-ecological system within normal environmental conditions was seen by the Guyanese CSO as being significantly jeopardized by the limited number of skilled people in the region. The inadequate provision and standards of education and skills training in Guyana meant that there was limited potential for the sustainable implementation of national and international conservation and development programs.

Exploration of regional resistance strategies for coping with temporary change was identified by the Guyanese CSO as having the greatest challenges out of all the viability categories. Selected indicators and associated data showed that community participation was weakened by the limited decision-making controls conferred by the national government. Land tenure for North Rupununi communities is currently limited to the immediate vicinities of community settlements, rather than over traditional land-use areas, and the serious socioeconomic situation restricts community support for activities that are not directly related to fulfilling their immediate survival and therefore restricting their abilities to cope with short-term stress. This position was seen as reducing the confidence of communities to internally support natural resource management initiatives for smoothing out challenges emerging from temporary environmental disturbance.

The flexibility of the North Rupununi social-ecological system for coping with a diversity of challenges within the environment was perceived by the Guyanese CSO as being limited by the overall health status and susceptibility to disease of the population. For example, malaria is endemic to the North Rupununi and is a major disease regularly affecting communities. In addition, showing initiative and the ability to think critically are necessary skills for maximizing flexibility to achieve established goals. Flexibility is also restricted by inadequate governance that would allow the emergence of a diversity of responses beyond the routine.

Adaptability to permanently changing environmental characteristics within the North Rupununi social-ecological system was seen by the Guyanese CSO as being highly dependent on individuals passing through several stages of training, from primary all the way to higher education. One particular initiative in the region, the Bina Hill Institute, is seen as beginning to have an impact on postsecondary school capacity building, but its effectiveness is perceived to be limited by lack of funds and teaching capacity.

Although ideal performance for coping with scarce resources within the environment was deemed as the least important of all the viability categories, it scored the highest within the Guyanese CSO analysis. This was because the two indicators of ideal performance, level of participation within sustainability initiatives and contribution to the development of new initiatives, scored highly, principally thanks to several incredibly motivated and determined individuals identified within the region.

In the identification of coexistence indicators, the communities of the North Rupununi were seen by the Guyanese CSO as probably the most advanced of Guyanese inland communities 
with regard to engaging in collaborative partnerships with national and international NGOs. In any one year, there are a number of initiatives being rolled out in the region in support of development, conservation, and/or health. The role of Iwokrama International Centre was seen as being especially instrumental in facilitating these partnerships. However, the global economic recession was seen as having placed significant pressures on national and international funding, although the North Rupununi communities were deemed to be well-placed for capturing any international interest in Guyana.

The Brazilian CSO carrying out the system viability analysis for the Tumucumaque region focused less on the current social, economic, and political conditions of the region, compared to the Guyanese CSO analysis, and instead employed a longitudinal perspective. The existence strategy for the Tumucumaque region focused on the historical account of how the indigenous communities ended up settling in the Tumucumaque region. In essence, the Tumucumaque region was seen as having enabled the existence of its unique social-ecological system because it acts as a refuge, an inaccessible and isolated territory away from the coast and navigable rivers that were rapidly colonized by European settlers. Thus, the indigenous communities were, and continue to be, able to exist in this region as a result of the protection bestowed upon it by the inaccessible territory. Ease of access to the region by nonindigenous people measured in terms of cost and/or time, therefore represented an indicator that originally enabled, and may still allow, the continuing existence of the indigenous community. In addition, the Tumucumaque region is perceived by the Brazilian CSO to still be in an extremely pristine state and has a low population density that allows communities to rely on traditional livelihood practices. Access to various natural resources for food, shelter, and other essential uses was also proposed as an indicator of existence. Increasing contact with nonindigenous communities was seen as having added to the health problems already experienced within the unforgiving rainforest environment. The presence and quality of health/ medical services was therefore proposed as another indicator strengthening the existence strategy of the indigenous communities within the Tumucumaque region. In recent years, the natural protection bestowed by the region's isolation and inaccessibility has been reduced as a result of increasing legal and illegal development encroaching on the region. Representation of indigenous peoples within an external platform is also seen as a mechanism through which communities can strengthen their existence strategy. Hence, the percentage of territory under official protection and the establishment of indigenous associations were therefore proposed as additional indicators for the existence strategy. Finally, NGO initiatives, such as cultural mapping and ranger courses, were seen as building capacity within the community for facing up to every day, routine challenges. The number of NGO led initiatives was therefore proposed as a final indicator for supporting the community existence strategy.

The ideal performance indicators selected by the Brazilian CSO mainly revolved around the theme of resource use efficiency. Indigenous communities were depicted as being increasingly challenged in trying to sustain a traditional livelihood near the relatively high density assistance centers established by missionaries and government institutions. Because a Western lifestyle, with associated consumption patterns, was seen as being difficult to achieve in such an isolated region, communities were portrayed as being still heavily reliant on traditional practices. However, a sedentary, semiurban lifestyle was seen as causing many problems in that local resources such as fish, game, and fertile soils were depicted as rapidly becoming exhausted. The significant reduction in mortality rates (back in 1997 only 3\% of the indigenous population of Tumucumaque was above 60 years of age) has resulted in an average $4 \%$ yearly growth rate of the population. There were concerns expressed by the Brazilian CSO that a high population density could not be sustained within a region that is highly isolated from the rest of the world. The indicator proposed for ideal performance was therefore based on achieving a low and sustainable population density. Another indicator associated with ideal performance was the availability of natural resources and their accessibility to the population.

The Brazilian CSO's interpretation of Tumucumaque region's flexibility strategies for coping with diversity within the environment is an account of the incredible flexibility inherent within a traditional indigenous community. Communities are described as having strong kinship ties through a tradition of intermarriages - the memory of these ties lasts through generations and allows families to maintain a network of support over time and space. This is especially important because traditional settlements have a very low "shelf-life"; traditional villages have an average life span of about 5 to 10 years, moving on when local resources start to run low. An indicator of flexibility was therefore proposed as being the strength of family ties. The great diversity of natural resource use is also highlighted as a source of flexibility. Food provision can be sourced through traditional rotational agriculture, fishing, hunting, and gathering of nontimber forest products such as honey. However, where traditional natural resources are in scarce supply as a result of high density, sedentary living around assistance centers, there has been an attempt to introduce more modern livelihood practices, including more intensive agriculture and animal rearing (with mixed success). The number of resources, both traditional and modern, commonly used is therefore proposed by the Brazilian $\mathrm{CSO}$ as an indicator of flexibility. Strength of cultural and traditional practices as well as ties to the forest within the younger generations are described as other potential flexibility indicators.

Within the resistance strategy exploration for the Tumucumaque region, a significant focus was given by the Brazilian CSO to developments being put in place to avoid the impact of increasing threats from mining, deforestation, mega infrastructure projects, and encroaching nonindigenous settlement/natural resource use. The analysis focused on the implementation of sustainable development policies as a counter measure to historical policies of opening up the Amazonian region to economic exploitation. Indicators of resistance were therefore proposed as the number of preservation and protection policies as a counterbalance to the number of development policies.

The Brazilian CSO's exploration of adaptability strategies for the region revolved instead around an extensive description of initiatives aimed at helping to transform the indigenous worldview to champion a modern conservation paradigm. Historically, the relative isolation of indigenous communities meant that they could continue with their traditional activities to meet their needs. However, increasing contact with the nonindigenous world, and 
the associated pressures for exploiting the region's natural resources, has meant that these indigenous communities have now been encouraged by some stakeholders, including the Brazil CSO that undertook the Tumucumaque regional system viability analysis, to become sustainability champions. Thus, there are a wide range of initiatives, from the training of indigenous rangers to the production of cultural maps, that are aimed at building capacity within the indigenous community to show the outside world that they are capable managers of a pristine natural environment. The idea of indigenous people as conservation champions has been promoted by a number of Brazilian regional CSOs and indigenous associations through a series of meetings and conferences, and this has culminated in a new federal policy, the National Policy on Land and Environmental Management and Indigenous Lands (PNGATI). The success of the PNGATI policy initiative was therefore seen as a key indicator of the adaptability strategy for the region. Also, the numbers of indigenous peoples trained in, and carrying out, environmental management, health and education was identified as an associated indicator for the regional adaptability strategy.

Within the frame of coexistence strategies, the Brazilian CSO discussed a progression from a situation where indigenous people were simply not considered as a system in coexistence with other social systems, to a situation where there is now an attempt to create a strong "indigenous system" identity that can compete against the interests of other social-ecological systems within the Amazonian, Brazilian, and international context, e.g., the industrial agribusiness social-ecological system. An indicator for the regional coexistence strategy was therefore proposed to be the strength of indigenous identity and representation within regional, national, and international deliberations. In more practical terms, another indicator of coexistence proposed by the Brazilian CSO was the number of indigenous peoples able to bridge the divide between traditional lifestyles and outside practices.

\section{Emerging cross-scalar environmental governance themes}

The indicator sets produced by the various stakeholders allowed us to identify common themes across the different systems of interest to explore synergies and/or conflicts. This was done by grouping the indicators identified by participants into emergent themes, an approach inspired by grounded theory (Charmaz 2006) where no a priori hypothesis was in place before the grouping exercise took place. However, within our analysis, we prioritized the indicators selected at community level to help identify the overarching themes, and then explored for compatibility of the indicators selected by the national CSOs. The level of fit of the indicators from the higher scales of analysis would allow us to identify the synergies and/or conflicts between indigenous community and national CSO perspectives on nested social-ecological system survival strategies.

Five themes, land rights, leadership, partnerships, lifestyle, and identity, emerged from the cross-scalar analysis. It is widely recognized that land tenure and rights are a prerequisite for effective natural resource management. System viability strategies that were heavily represented by a rich diversity of indicators within the land rights theme included existence and resistance, and our analysis shows that there are many synergies across the different systems of interest. At the local community scale, participants selected indicators that focused on securing access to territory to maintain traditional land-use practices (subsistence farming, fishing, hunting, building materials, and access to medicinal plants) and the ability to exploit future incomegenerating activities (such as timber harvesting and payments for ecosystem services). At the higher scales of analysis, national CSO participants selected indicators that emphasized the need for indigenous land rights to maintain resource quality and access, and for effective policy implementation. Thus, we were able to identify synergies within the land rights theme between the various systems of interest at the different scales of analysis: supporting community viability by allocating land rights could also sustain regional social-ecological systems. However, although on paper we see consensus among stakeholders across scales on the importance of indigenous land rights, in practice most Guiana Shield countries are far from demonstrating appropriate indigenous land rights implementation. Both Guyana and Suriname are nonsignatories of the Convention on Indigenous and Tribal Peoples (Convention ILO no. 169). In Suriname and Venezuela, few indigenous groups have land tenure. Although the Guyanese government is committed to increasing indigenous land rights through the Amerindian Act of 2006, limited progress has been achieved to date; most indigenous communities have been given land tenure around small zones surrounding settlements, rather than the customary territories that they have traditionally used to maintain their livelihoods. It is also notable that Guyana's 2006 Amerindian Act does not overrule pre-2006 mining and forestry concessions, even if they are located on titled indigenous land. This situation across the Guiana Shield will only be exacerbated as pressures from mining, logging, and carbon projects grow.

Closely linked to land rights are issues of governance that were strongly represented by indicators from the resistance and ideal performance strategies. Good leadership and solidarity were identified as survival indicators by community participants, particularly during times of variable pressures and resource scarcity. During community engagement events, participants identified community cohesion to be strong, but leadership and respect for customary rules was repeatedly questioned, including the extent to which leaders had autonomy and support in decision making. At regional scales, stakeholders identified control of corruption, and effective leadership, as key determinants of regional social-ecological viability. However, at this scale all the Guiana Shield countries (except French Guiana) have poor scores across a range of governance indicators (World Bank 2014). Guyana, in particular, has severe problems in the control of corruption and regulatory quality in the formulation and implementation of policies and regulations permitting and promoting private sector development, such as in the resource extraction industries.

Partnerships require involvement of multiple scales of organization, so it should come as no surprise that there were substantial indicator representations under the coexistence system response by stakeholders at all scales of analysis. We identified significant subthemes within the indicator selection, including the generation of funding streams, and enabling capacity-building opportunities through cooperation among indigenous associations, national and international NGOs, governmental institutions, and international bodies. At the local 
scale, the Guyanese communities reported satisfactory relationships with local/national partners on the themes of natural resource management. For example, the North Rupununi District Development Board (NRDDB), a local CSO that has been acting as a bridge between communities and national / international stakeholders, has led to job opportunities in the region and capacity building in the areas of ecotourism, resource management, research, and administration. However, for the Tumucumaque communities, relationships with stakeholders were deemed inadequate and they expressed severe disappointment with the lack of sustained results from partnerships. Indeed, capacity-building activities, in particular, take considerable effort and time, and there was little evidence for sustained and stable cooperation and funding at regional and international scales to support collaborative initiatives at the local scale.

Lifestyle was a highly significant theme emerging primarily at the community level that was characterized by the adaptability strategy response and comprised the requirements for built infrastructure (roads, modern housing), technologies (transportation, communication), health services (medicines and medical equipment), livelihoods (paid employment, participation in formal education), and access to modern consumer goods (clothing, televisions, imported foods, entertainment). Technologies, particularly information and communication technologies (ICTs), were also key indicators identified by the national CSO participants that we were also able to associate with the adaptability response. ICTs can play a pivotal role in ecotourism and other natural resource based enterprises, as well as a means of exchanging information locally and with stakeholders at other scales.

As well as lifestyle, identity also featured strongly as a key component of community viability, especially the system viability strategy of resistance characterized by those indicators that focused on retaining indigenous traditional practices, e.g., food preparation or celebrations, and language. This reflects current tensions at the local level between maintaining traditions and embracing modernity (Berardi et al. 2013a). We were able to identify these tensions within the indicators selected by stakeholders at higher scales of analysis. For example, the Brazilian CSO working on the Tumucumaque regional analysis suggested indigenous lifestyle changes as a threat to socialecological system viability. The Brazilian CSO strongly promoted the idea of reshaping traditional indigenous lifestyles into a narrative of ecological custodians, for example, through their support for a new federal policy, the National Policy on Land and Environmental Management and Indigenous Lands (PNGATI). In essence, indigenous communities would be actively encouraged to abandon their subsistence nonengagement approach with modern society, and instead take on professional roles as park rangers and environmental managers to protect, and be paid for, the global ecosystem services that are provided within their territories.

However, the long-term viability of these higher scale socialecological systems, promoting indigenous peoples as conservation champions, would require the preservation of indigenous identity, because large territorial areas have been set aside for indigenous communities primarily because of their distinctive culture and land-use practices. However, data on local level indicators proposed by community participants showed that a majority of young people were less keen to speak their indigenous language compared to their parents and did not always want to participate in strenuous, labor-intensive traditional activities. Many communities showed signs of mass emigration of youth to nonindigenous settlements and mining areas, while at the same time, indigenous communities were increasingly confronted by the physical presence of nonindigenous individuals, e.g., illegal gold miners, government officials, teachers, health workers, and conservation and development practitioners, and virtual manifestations, e.g., DVDs of Hollywood films, access to Internet pornography. Although the rhetoric of community, national, and international conservation CSOs emphasize the compatibility between traditional indigenous lifestyles and national / international conservation initiatives, our analysis shows that, on the ground, many communities may potentially support a much more rapid transition toward a Western lifestyle to the detriment of conservation initiatives. It is therefore imperative that conservation policies directly address the sustainable lifestyle needs of communities, including infrastructure development, if they are not to be undermined by the need by community members, especially the youth, from seeking an alternative Western lifestyle outside of the communities. It is clear that, once networked into global socioeconomic systems, these communities can no longer go back to an isolated, preglobalization lifestyle. Thus, the challenge is to find ways in which communities can constructively adapt to globalization without totally losing their indigenous cultures and lifestyles, and degrading their natural environment.

\section{Cross-scalar challenges}

As a result of the indicators selected by various participants, and the values attributed to them by these participants, we were unable to attribute a clean bill of health to any of the systems of interest proposed by stakeholders at any scale (Fig. 3); all systems were seen as struggling to face up to various cross-scalar challenges undermining different system viability strategies. Cash et al. (2006) identify three common features of these scale related challenges: ignorance, mismatch, and plurality.

Ignorance comes about when, for example, national policies adversely constrain local policies, local actions aggregate into large-scale problems, and/or short-term solutions aggregate into long-term problems. In our analysis, some indicators identified by stakeholders at regional and international scales raise alarm with regard to the level of potential investment for large-scale infrastructure development within indigenous territories, as part of mega infrastructure plans, including dam building, transnational roads, and large-scale mining projects. Mineral extraction, gold in particular, is being encouraged directly through tax incentives across the Guiana Shield countries (Berardi et al. 2013b) and indirectly through corruption and the absence of control. This not only undermines the social-ecological integrity of whole systems at more local scales (Hammond et al. 2007, Colchester and La Rose 2010), but is also in direct crossscalar conflict with land rights policies and conservation and climate change mitigation strategies.

There are also issues of mismatch between human institutions governing resources and the biogeophysical scale of the resource, either in space or time (Cumming et al. 2006). For example, Berkes 
(2006) shows how in the case of managing migratory tuna, both the community and the national levels do not match the geographical scale of the fish resource. An international agreement may become necessary to solve the scale discrepancy, but the more technical approaches to management at this level can potentially isolate local fishing communities. This latter point is another example of mismatch, where there are incongruities between the scale of what is known about the world and the scale at which decisions are made and action taken (Lebel 2006). In the Guiana Shield, there are a number of these kinds of incompatibilities between scales. For example, the forest and savanna ecosystems of the North Rupununi turn into a large wetland system during the rainy season, connecting water, species, and people. Although these interconnections are well known by academics and local people (Wetlands Partnership 2006, 2008), the focus of national policies such as the Low Carbon Development Strategy, and programs such as REDD+ are on conserving forests while converting savannas to potential largescale agriculture, with little apparent thought for the implications of land-use change for pollution dispersion and loss of soil carbon across the whole system. Indeed, the Guyanese government is incentivizing foreign agricultural investment to create rice mega farms in the Rupununi (Stabroek News 2013). At the same time, local indigenous knowledge is not seen as legitimate or credible by national or international actors and little conservation planning begins from the bottom-up. Our analysis indicates that, although the communities in Tumucumaque and the North Rupununi are relatively organized within indigenous associations, disparities are further entrenched by a consistent lack of indigenous voice and representation at regional, national, and international scales of decision making, thereby creating weak links between local and higher scale social-ecological systems.

\section{DISCUSSION}

In this paper we focused on outlining the selection of indicators by different stakeholders operating at a range of levels of decision making within the Guiana Shield region. We specifically tried to avoid a pseudoobjective stance to indicator selection, allowing all participants to focus on a free, unguided selection and description of indicators within the six system viability strategies. As such, system viability was clearly able to generate a rich and varied exploration at all levels of analysis. It encouraged participants to investigate areas outside their own immediate interests and disciplines of expertise, while at the same time allowed the identification of cross-scalar themes/challenges that could be fed into environmental governance and policy making. However, it is a conceptual model that required facilitators to provide practical examples to overcome difficulties by stakeholders, at all levels of analysis, in grasping the concepts and developing their own indicators. We therefore did experience participants initially adopting some of our example indicators as their own. However, through a participatory, bottom-up and reflective process of indicator discovery and critique, which involved many months of validation with stakeholders, the resulting work represents a true expression of what the participants themselves understood to have an impact on the viability of their systems of interest. This reiterates the approach of postdevelopment theorists (e.g., Escobar 1995) who have emphasized the need for decentralized and localized methods in creating positive change.

The system viability approach emphasizes the significance of appreciating a particular stakeholder's perspective, even if the measurement of a particular indicator is dependent on a subjective judgement by one or more evaluators, based on their personal experiences. Thus, our acceptance of qualitative and subjective indicators determining the survival strategies of various systems of interest has allowed the surfacing of distinct perspectives, from national CSO participants to indigenous communities. Our aim was to be explicit in representing the perspective of a range of stakeholders, going beyond the typical dominance of highly trained professional experts in determining development and conservation strategies, and measures of their success at various levels of analysis.

Our qualitative approach has also meant that many of the indicators selected would be extremely difficult to measure precisely in practice. For example, strength of indigenous identity was deemed to be an important coexistence strategy for the viability of the Tumucumaque social-ecological system, but would be difficult to measure precisely and objectively as Weaver (2001:240) illustrates:

There is little agreement on precisely what constitutes an
indigenous identity, how to measure it, and who truly has
it. Indeed, there is not even a consensus on appropriate
terms. Are we talking about Indians, American Indians,
Natives, Native Americans, indigenous people, or First
Nations people? Are we talking about Sioux or Lakota?
Navajo or Dine? Chippewa, Ojibway, or Anishnabe?
Once we get that sorted out, are we talking about race,
ethnicity, cultural identity, tribal identity, acculturation,
enculturation, bicultural identity, multicultural identity,
or some other form of identity?

This is a clear example of a qualitative and subjective indicator that matters greatly to the indigenous communities, but for which quantitative and objective measurements would be difficult to compile. Not everything that matters can be measured quantitatively and objectively, and it would be absurd to exclude such an important indicator, because it lacked scientific empiricism, from decision-making deliberations that would impact on the long-term survival of a community within its local environment.

The challenge of plurality is the failure to recognize heterogeneity in the way indicators are perceived and valued by different actors (Jones et al. 2011), and the (incorrect) assumption that there is a single set of solutions that can be applied to the whole system and all the subsystems contained within (Roe 1991). In our study, we attempted to mitigate this by taking a big picture view of the situation, developing different models of decision making that have a particular focus on boundary judgements by different stakeholders. We enabled indigenous communities themselves to decide on which indicators are important for their own survival, and then we moved up to the next level of stakeholder participation: representatives from Brazilian and Guyanese CSOs for the subregional analysis; and representatives from international CSOs for the Guiana Shield region as a whole. The outcomes, therefore, are more likely to enable more appropriate contributions to decision making than those that match the criteria and preferences of isolated scale- or level-bound group of actors.

At a time when many stakeholders are firefighting from one emergency to another, and/or jumping on the popular bandwagon for whatever policy and/or disaster response has captured media attention at that moment in time, integrating all the issues into a 
single framework, such as Figure 3, can help stakeholders to work together to identify weaknesses and "joined-up" strategies for tackling current and emerging challenges. We found that the system viability approach can be used with a disparate variety of stakeholders with different types of capacity and expertise, to work together and learn about how their experiences, understandings, and values can contribute toward deriving a wide selection of indicators that can then be analyzed and compared simultaneously to identify conflicts and/or synergies.

The system viability approach also offers an immediate means of testing the real world impact of policies formed at various levels, while taking into account the multiple factors associated with the implementation of those policies across scales. Indeed, a major issue with international policies is that they focus on particular themes, from biodiversity conservation to climate change mitigation and adaptation, while struggling to demonstrate joined-up thinking. For example, recent reviews of payments for ecosystem services schemes indicate that there is a bias toward biophysical and monetary value domains (Vihervaara et al. 2010, Seppelt et al. 2011, Chan et al. 2012), prioritizing marketable provisioning services, while obscuring the socio-cultural importance given by stakeholders to regulating and cultural services (Martín-López et al. 2014). The system viability approach demonstrates that the local impact of the implementation of any policy at the international or national level may be many-faceted; although it may encourage local capacity building for adaptation to some of the new realities brought about by global changes, it might threaten the very existence of communities by undermining key survival responses. There is a real danger that these policies might limit community viability if they are going to reduce access to resources and infrastructure development, for example, encouraging restrictive, punitive legislation or the designation of traditional indigenous territories as protected areas excluding indigenous traditional practices. The competition among various priorities, and how these ultimately manifest themselves at the local community level, therefore, becomes clearly evident in the system viability approach.

In our case, we have been able to use the results of the cross-scalar analysis to inform policy-making initiatives in the Guiana Shield region. For example, the themes of land rights, leadership, partnerships, lifestyle, and identity in support of communityowned solutions were discussed and subsequently included in the 2015-2020 program of the Guiana Shield Facility (United National Development Programme), a multidonor funding facility for the region. Critically, rather than a separate stream of work, the inclusion of the themes was integrated within larger social-ecological challenges, such as gold mining, forest management, and water quality monitoring. Thus, rather than being purely an academic exercise, we were able to apply the outcomes of the system viability approach directly to influencing policy making.

\section{CONCLUSION}

Given that the forces shaping the Amazon Biome extend far beyond a local context and know no political boundaries, we can no longer work on pieces of the puzzle in isolation from one another. Rather, we must address the biome as a whole to secure the viability of the entire system (Flores et al 2010:8).
The Guiana Shield region of the Amazon Biome is one of the few large tracks of pristine rain forest in the world, and home to many indigenous cultures still practicing sustainable, traditional lifestyles. However, logging, mining, large infrastructure projects, and other significant interventions are increasingly threatening the survival of these integrated social-ecological systems. Environmental governance initiatives at a range of scales are emerging, but these are rarely joined-up and are often undermined by other unsustainable initiatives put in place by the very same decision makers. Our research demonstrates a framework for critical, big picture systemic cross-scalar analyses of socialecological systems engaging a wide variety of stakeholders. Through an appreciation and integration of a range of perspectives, we were able to provide assessments of challenges, and resulting solutions, that are more politically and ecologically sustainable (Berkes 2006, Cash et al. 2006). The aim of our analysis was to identify how to enhance the survival prospects of the Guiana Shield as a whole, the viability of the entire system through a participatory bottom-up process. We certainly need to avoid the mistakes of some environmental governance initiatives that have focused on specialized interest groups, such as, for example, biodiversity conservation, which have sometimes resulted in the promotion of protected areas resulting in the exclusion of traditional land uses (Adams and Hutton 2007, Brockington et al. 2008).

With the recent upsurge in environmental governance initiatives, such as payments for ecosystem services and climate change mitigation, we once again risk the dominance of decision making by powerful groups, comprising G8 governments, multinational corporations, and nongovernmental organizations. Stakeholders at all scales need to ask the following: How can the voice of multiple stakeholders at different levels of decision making be integrated? Which policy interventions would have the most positive effect on the whole system and its constituent subsystems, including local communities and their environment? What aspects of environmental governance initiatives are beneficial or damaging to the integrity of local and regional social-ecological systems? Where can maximum synergistic leverage be achieved? If environmental governance schemes are to be successfully implemented on the ground in ways that effectively protect biological and cultural diversity, then integrative and participative processes, such as the system viability approach, should be encouraged at all levels of decision making.

\section{Responses to this article can be read online at: http://www.ecologyandsociety.org/issues/responses. $\mathrm{php/7865}$}

\section{Acknowledgments:}

We would like to thank all the communities of the North Rupununi, Guyana and Tumucumaque, Brazil, for their participation in this research. A special thanks to Cloude de Souza for his System Viability analysis of the Tumucumaque region. Thank you also to the anonymous reviewers for their very useful comments. This research has been funded by the Environment Programme, Management of Natural Resources, DG Research and Innovation, European Commission 7th Framework. 


\section{LITERATURE CITED}

Adams, W. M., and J. Hutton. 2007. People, parks and poverty: political ecology and biodiversity conservation. Conservation and Society 5:147-148.

Ahlborg, H., and A. J. Nightingale. 2012. Mismatch between scales of knowledge in Nepalese forestry: epistemology, power, and policy implications. Ecology and Society 17(4):16. http://dx. doi.org/10.5751/ES-05171-170416

Ashby, W. R. 1956. An introduction to cybernetics. Wiley, New York, New York, USA. http://dx.doi.org/10.5962/bhl.title.5851

Beer, S. 1985. Diagnosing the system for organizations. John Wiley, London, UK.

Béné, C., L. Evans, D. Mills, S. Ovie, A. Raji, A. Tafida, A. Kodio, F. Sinaba, P. Morand, J. Lemoalle, and N. Andrew. 2011. Testing resilience thinking in a poverty context: experience from the Niger River basin. Global Environmental Change 21:1173-1184. http:// dx.doi.org/10.1016/i.gloenvcha.2011.07.002

Berardi, A., J. Mistry, C. Tschirhart, J. Abraham, and E. Bignante. 2012. Report on the cross-scalar interactions and compatibilities governing sustainable development and ecosystem service management of the Guiana Shield. The Open University, Milton Keynes, UK. [online] URL: http://projectcobra.org/wp-content/ uploads/D2.1Reportoncross-scalarinteractionsandcompatibilities3. pdf

Berardi, A., J. Mistry, C. Tschirhart, C. Verwer, R. Glastra, G. de Ville, O. Davis, C. de Souza, L. Haynes, R. Benjamin, R. Xavier, G. Albert, D. Jafferally, E. Bignante, and J. Abraham. $2013 b$. Second report on the cross-scalar interactions and compatibilities governing sustainable development and ecosystem service management of the Guiana Shield: drivers of social and environmental degradation, and policy responses. The Open University, Milton Keynes, UK. [online] URL: http:// projectcobra.org/wp-content/uploads/Revised-COBRA-D2-115. pdf

Berardi, A., C. Tschirhart, J. Mistry, E. Bignante, L. Haynes, G. Albert, R. Benjamin, R. Xavier, and D. Jafferally. 2013a. From resilience to viability: a case study of indigenous communities of the North Rupununi, Guyana. EchoGéo 24. [online] URL: http:// echogeo.revues.org/13411

Berkes, F. 2006. From community-based resource management to complex systems. Ecology and Society 11(1):45. [online] URL: http://www.ecologyandsociety.org/vol11/iss1/art45/

Bertalanfy, L. V. 1956. General systems theory. General Systems Yearbook 1:1-10.

Bignante, E. 2010. The use of photo-elicitation in field research: exploring Maasai representation and use of natural resources. EchoGéo 11. [online] URL : http://echogeo.revues.org/ index11622.html. http://dx.doi.org/10.4000/echogeo.11622

Blom, B., T. Sunderland, and D. Murdiyarso. 2010. Getting REDD to work locally: lessons learned from integrated conservation and development projects. Environmental Science \& Policy 13:164-172. http://dx.doi.org/10.1016/j.envsci.2010.01.002

Bond, I., M. Grieg-Gran, S. Wertz-Kanounnikoff, P. Hazlewood, S. Wunder, and A. Angelsen. 2009. Incentives to sustain forest ecosystem services: a review and lessons for REDD. Natural Resource Issues No. 16. International Institute for Environment and Development, London, UK, with CIFOR, Bogor, Indonesia, and World Resources Institute, Washington D.C., USA.

Bossel, H. 1992. Modellbildung und Simulation: Konzepte, Verfahren und Modelle zum Verhalten dynamischer Systeme. Vieweg, Braunschweig, Germany. http://dx.doi.org/10.1007/978$\underline{-3-322-83658-8}$

Bossel, H. 1998. Ecological orientors: emergence of basic orientors in evolutionary self organization. Pages 19-33 in F. Müller and M. Leupelt, editors. Eco targets, goal functions, and orientors. Springer-Verlag, Berlin, Germany . http://dx.doi. org/10.1007/978-3-642-58769-6_3

Bossel, H. 1999. Indicators for sustainable development - theory, method, applications. A report to the Balaton Group. International Institute for Sustainable Development, Winnipeg, Manitoba, Canada.

Bossel, H. 2001. Assessing viability and sustainability: a systemsbased approach for deriving comprehensive indicator sets. Conservation Ecology 5(2):12. [online] URL: http://www. consecol.org/vol5/iss2/art12/

Bossel, H. 2007. Systems and models: complexity, dynamics, evolution, sustainability. Books on Demand, Norderstedt, The Netherlands.

British Broadcasting Corporation (BBC). 2013. Brazil says Amazon deforestation rose $28 \%$ in a year. BBC, London, UK. [online] URL: http://www.bbc.co.uk/news/world-latin-america-24950487

Brockington, D., R. Duffy, and J. Igoe, editors. 2008. Nature unbound: conservation, capitalism and the future of PAs. Earthscan, London, UK.

Buizer, M., B. Arts, and K. Kok. 2011. Governance, scale, and the environment: the importance of recognizing knowledge claims in transdisciplinary arenas. Ecology and Society 16(1):21. [online] URL: http://www.ecologyandsociety.org/vol16/iss1/ $\underline{\operatorname{art} 21 /}$

Bunch, M. J. 2003. Soft systems methodology and the ecosystem approach: a system study of the Cooum River and environs in Chennai, India. Environmental Management 31(2):0182-0197. http://dx.doi.org/10.1007/s00267-002-2721-8

Carpenter, S. R., H. A. Mooney, J. Agard, D. Capistrano, R. S. DeFries, S. Díaz, T. Dietz, A. K. Duraiappah, A. Oteng-Yeboah, H. M. Pereira, C. Perrings, W. V. Reid, J. Sarukhan, R. J. Scholes, and A. Whyte. 2009. Science for managing ecosystem services: beyond the Millennium Ecosystem Assessment. Proceedings of the National Academy of Sciences 106(5):1305-1312. http://dx. doi.org/10.1073/pnas.0808772106

Carpenter, S. R., B. Walker, J. M. Anderies, and N. Abel. 2001. From metaphor to measurement: resilience of what to what? Ecosystems 4:765-781. http://dx.doi.org/10.1007/s10021-001-0045-9

Cash, D. W., W. N. Adger, F. Berkes, P. Garden, L. Lebel, P. Olsson, L. Pritchard, and O. Young. 2006. Scale and cross-scale dynamics: governance and information in a multilevel world. Ecology and Society 11(2):8. [online] URL: http://www.ecologyandsociety. org/vol11/iss2/art8/ 
Chan, K. M. A., A. D. Guerry, P. Balvanera, S. Klain, T. Satterfield, X. Basurto, A. Bostrom, R. Chuenpagdee, R. Gould, B. S. Halpern, N. Hannahs, J. Levine, B. Norton, M. Ruckelshaus, R. Russell, J. Tam, and U. Woodside. 2012. Where are cultural and social in ecosystem services? A framework for constructive engagement. BioScience 62(8):744-756. http://dx.doi.org/10.1525/ bio.2012.62.8.7

Charmaz, K. 2006. Constructing grounded theory: a practical guide through qualitative analysis. Sage, London, UK.

Chene, M. 2010. Overview of corruption and anti-corruption in Guyana, with reference to natural resource sectors. U4 AntiCorruption Resource Centre, Bergen, Norway.

Checkland, P. 1981. Systems thinking systems practice. John Wiley, Chichester, UK.

Chung Tiam Fook, T. 2013. A ‘win-win' strategy for all? Guyana’s climate change strategies and implications for indigenous communities. Caribbean Journal of International Relations \& Diplomacy 1(1):3-38.

Churchman, C. W. 1968. The systems approach. Dell, New York, New York, USA.

Colchester, M., and J. La Rose. 2010. Our land, our future: promoting indigenous participation and rights in mining, climate change and other natural resource decision-making in Guyana. Amerindian Peoples Association, Guyana, Forest Peoples Programme, Moreton-in-Marsh, UK, and The North-South Institute, Ottawa, Ontario, Canada.

Cowling, R. M., B. Egoh, A. T. Knight, P. J. O’Farrell, B. Reyers, M. Rouget, D. J. Roux, A. Welz, and A. Wilhelm-Rechman. 2008. An operational model for mainstreaming ecosystem services for implementation. Proceedings of the National Academy of Sciences 105(28):9483-9488. http://dx.doi.org/10.1073/pnas.0706559105

Cumming, G. S., D. H. M. Cumming, and C. L. Redman. 2006. Scale mismatches in social-ecological systems: causes, consequences, and solutions. Ecology and Society 11(1):14. [online] URL: http://www.ecologyandsociety.org/vol11/iss1/ art14/

Danielsen, F., T. Adrian, S. Brofeldt, M. van Noordwijk, M. K. Poulsen, S. Rahayu, E. Rutishauser, I. Theilade, A. Widayati, N. The An, T. Nguyen Bang, A. Budiman, M. Enghoff, A. E. Jensen, Y. Kurniawan, Q. Li, Z. Mingxu, D. Schmidt-Vogt, S. Prixa, V. Thoumtone, Z. Warta, and N. Burgess. 2013. Community monitoring for REDD+: international promises and field realities. Ecology and Society 18(3):41. http://dx.doi.org/10.5751/ ES-05464-180341

Davis, C., L. Williams, S. Lupberger, and F. Daviet. 2013. Assessing forest governance. The governance of forests initiative indicator framework. World Resources Institute, Washington D. C., USA.

Eden, C., and F. Ackermann. 1988. Making strategy: the journey of strategic management. Sage, London, UK.

Escobar, A. 1995. Encountering development: the making and unmaking of the third world. Princeton University Press, Princeton, New Jersey, USA.

Flores, M., U. Lopes da Silva Jr, H. Malone, M. Panuncio, J. C. Riveros, S. Rodrigues, R. Silva, S. Valenzuela, D. Arancibia, P.
Bara-Neto, and M. Symington. 2010. WWF's Living Amazon Initiative. A comprehensive approach to conserving the largest rainforest and river system on Earth. WWF, Gland, Switzerland. [online] URL: http://awsassets.panda.org/downloads/ living amazon strategy summary final.pdf

Forrester, J. W. 1961. Industrial dynamics. Wright-Allen Press, Cambridge Massachusetts, USA.

Gallopín, G. C. 2006. Linkages between vulnerability, resilience, and adaptive capacity. Global Environmental Change 16:293-303. http://dx.doi.org/10.1016/j.gloenvcha.2006.02.004

Griffiths, T., and L. Anselmo. 2010. Indigenous peoples and sustainable livelihoods in Guyana: an overview of experiences and potential opportunities. Amerindian Peoples Association, Georgetown, Guyana, Forest Peoples Programme, Moreton-inMarsh, UK, and The North-South Institute, Ottawa, Ontario, Canada. [online] URL: http://www.forestpeoples.org/sites/fpp/ files/publication/2010/08/guyanaiplivelihoodsjun10eng.pdf

Hammond, D. S., editor. 2005. Tropical forests of the Guiana Shield: ancient forests in a modern world. CABI, Cambridge, Massachusetts. http://dx.doi.org/10.1079/9780851995366.0000

Hammond, D. S., V. Gond, B. de Thoisy, P.-M. Forget, and B. P. E. DeDijn. 2007. Causes and consequences of a tropical forest gold rush in the Guiana Shield, South America. Ambio 36:661-670. http://dx.doi.org/10.1579/0044-7447(2007)36[661:CACOAT] 2.0. $\mathrm{CO} ; 2$

Ison, R. L., K. B. Collins, and P. J. Wallis. 2015. Institutionalising social learning: towards systemic and adaptive governance. Environmental Science \& Policy 53(Part B):105-117. http://dx.doi. org/10.1016/j.envsci.2014.11.002

Jones, N. A., H. Ross, T. Lynam, P. Perez, and A. Leitch. 2011. Mental models: an interdisciplinary synthesis of theory and methods. Ecology and Society 16(1):46. [online] URL: http:// www.ecologyandsociety.org/vol16/iss 1/art46/

Keohane, R. O., P. M. Haas, and M. A. Levy. 1993. The effectiveness of international environmental institutions. Pages 3-24 in P. M. Haas, R. O. Keohane, and M. A. Levy, editors. Institutions for the Earth: sources of effective international environmental protection. MIT Press, Cambridge, Massachusetts, USA.

Lebel, L. 2006. The politics of scale in environmental assessments. Pages 37-57 in W. V. Reid, F. Berkes, T. J. Wilbanks, and D. Capistrano, editors. Bridging scales and knowledge systems. Concepts and applications in ecosystem assessment. Island Press, Washington, D.C., USA.

Lunch, N., and C. Lunch. 2006. Insights into participatory video. InsightShare, Oxford, UK.

Martin, A., S. McGuire, and S. Sullivan. 2013. Global environmental justice and biodiversity conservation. Geographical Journal 179(2):122-131. http://dx.doi.org/10.1111/geoj.12018

Martín-López, B., E. Gómez-Baggethun, M. García-Llorente, and C. Montes. 2014. Trade-offs across value-domains in ecosystem service assessment. Ecological Indicators 37:220-228. http://dx.doi.org/10.1016/j.ecolind.2013.03.003

Matthews, H. D., T. L. Graham, S. Keverian, C. Lamontagne, D. Seto, and T. J. Smith. 2014. National contributions to observed 
global warming. Environmental Research Letters 9(1). http://dx. doi.org/10.1088/1748-9326/9/1/014010

Meadows, D. H., D. L. Meadows, J. Randers, and W. W. Behrens. 1972. The limits to growth: a report for the Club of Rome's Project on the Predicament of Mankind. Earthscan, London, UK. http:// dx.doi.org/10.1349/ddlp.1

Mistry, J. 2014. Natural resource management: a critical appraisal. Pages 361-365 in V. Desai, and R. Potter, editors. The companion to development studies. Routledge, Abingdon, UK.

Mistry, J., and A. Berardi. 2012. The challenges and opportunities of participatory video in geographical research: exploring collaboration with indigenous communities in the North Rupununi, Guyana. Area 44:110-116. http://dx.doi.org/10.1111/ j.1475-4762.2011.01064.x

Mistry, J., A Berardi, E. Bignante, and C. Tschirhart. 2015. Between a rock and a hard place: ethical dilemmas of local community facilitators doing participatory projects. Geoforum 61:27-35. http://dx.doi.org/10.1016/j.geoforum.2015.02.010

Mistry, J., A. Berardi, and D. Mcgregor. 2009. Natural resource management and development discourses in the Caribbean: reflections on the Guyanese and Jamaican experience. Third World Quarterly 30:969-989. http://dx.doi.org/10.1080/0143659$\underline{0902959222}$

Mistry, J., A. Berardi, M. Simpson, O. Davis, and L. Haynes. 2010. Using a systems viability approach to evaluate integrated conservation and development projects: assessing the impact of the North Rupununi Adaptive Management Process, Guyana. Geographical Journal 176(3):241-252. http://dx.doi.org/10.1111/ j.1475-4959.2010.00357.x

Mistry, J., A. Berardi, C. Tschirhart, E. Bignante, L. Haynes, R. Benjamin, G. Albert, R. Xavier, D. Jafferally, and G. De Ville. 2014a. Indigenous identity and environmental governance in Guyana, South America. Cultural Geographies. http://dx.doi. org/10.1177/1474474014560998

Mistry, J., E. Bignante, and A. Berardi. 2014b. Why are we doing it? Exploring participant motivations within a participatory video project. Area http://dx.doi.org/10.1111/area.12105

Müller, F., and M. Leupelt, editors. 1998. Eco targets, goal functions, and orientors. Springer-Verlag, New York, New York, USA. http://dx.doi.org/10.1007/978-3-642-58769-6

Nakashima, D. J., K. Galloway McLean, H. D. Thulstrup, A. Ramos Castillo, and J. T. Rubis 2012. Weathering uncertainty: traditional knowledge for climate change assessment and adaptation. UNESCO, Paris, France.

Odum, E. P. 1969. The strategy of ecosystem development. Science 164:262-270. http://dx.doi.org/10.1126/science.164.3877.262

Peskett, L., D. Huberman, E. Bowen-Jones, G. Edwards, and J. Brown. 2008. Making REDD work for the poor. Poverty Environment Partnership (PEP) Policy Brief. ODI/IUCN, London, UK.

Pierre, J., and B. G. Peters. 2000. Governance, politics, and the state. St. Martin's, New York, New York, USA.

Reed, M. S., E. D. G. Fraser, and A. J. Dougill. 2006. An adaptive learning process for developing and applying sustainability indicators with local communities. Ecological Economics 59:406-418. http://dx.doi.org/10.1016/j.ecolecon.2005.11.008

Roe, E. M. 1991. Development narratives, or making the best of blueprint development. World Development 19(4):287-300. http:// dx.doi.org/10.1016/0305-750x(91)90177-j

Seppelt, R., C. F. Dormann, F. V. Eppink, S. Lautenbach, and S. Schmidt. 2011. A quantitative review of ecosystem service studies: approaches, shortcomings and the road ahead. Journal of Applied Ecology 48:630-636. http://dx.doi.org/10.1111/j.1365-2664.2010.01952. $\underline{x}$

Stabroek News. 2013. Mega farm by Bajan investors taking shape in Rupununi. 16 March. [online] URL: http://www.stabroeknews. com/2013/news/stories/03/16/mega-farm-by-bajan-investors-takingshape-in-rupununi/

Taylor, J. 2006. Indigenous peoples and indicators of well-being: an Australian perspective on UNPFII global frameworks. Working Paper No. 33/2006. Centre for Aboriginal Economic Policy Research, The Australian National University, Canberra, Australia. [online] URL: http://caepr.anu.edu.au/Publications/ WP/2006WP33.php

Termeer, C. J. A. M., A. Dewulf, and M. van Lieshout. 2010. Disentangling scale approaches in governance research: comparing monocentric, multilevel, and adaptive governance. Ecology and Society 15(4):29. [online] URL: http://www. ecologyandsociety.org/vol15/iss4/art29/

Ulrich, W. 1987. Critical heuristics of social systems design. European Journal of Operational Research 31(3):276-283. http:// dx.doi.org/10.1016/0377-2217(87)90036-1

Vihervaara, P., M. Rönkä, and M. Walls. 2010. Trends in ecosystem service research: early steps and current drivers. Ambio 39:314-324. http://dx.doi.org/10.1007/s13280-010-0048-x

Warburton, D., editor. 2009. Community and sustainable development: participation in the future. Earthscan, London, UK.

Weaver, H. 2001. Indigenous identity: what is it and who really has it? American Indian Quarterly 25(2):240-255. http://dx.doi. org/10.1353/aiq.2001.0030

Wetlands Partnership. 2006. State of the North Rupununi Report. Georgetown, Guyana.

Wetlands Partnership. 2008. The North Rupununi Adaptive Management Process (NRAMP). Georgetown, Guyana.

White, S. A., editor. 2003. Participatory video: images that transform and empower. Sage, London, UK.

Wunder, S., S. Engel, and S. Pagiola. 2008. Taking stock: a comparative analysis of payments for environmental services programs in developed and developing countries. Ecological Economics 65: 834-852. http://dx.doi.org/10.1016/j.ecolecon.2008.03.010

World Bank. 2014. The worldwide governance indicators. World Bank, Washington, D.C., USA. [online] URL: http://info. worldbank.org/governance/wgi/index.aspx\#home 